\title{
WORK IMPROVEMENT OF AIR-AND-SCREEN CLEANER OF COMBINE HARVESTER
}

\author{
Nikolay Aldoshin, Otari Didmanidze, Nikolay Lylin, Maxim Mosyakov \\ Russian Timiryazev State Agrarian University, Russia \\ naldoshin@yandex.ru
}

\begin{abstract}
The work of the air-and-screen cleaner of a grain combine harvester is considered. Flows of grainstraw heap supplied for cleaning are evaluated. The methods of splitting the heap into grain and nongrain parts are described. To improve the work of the grain combine harvester cleaner, several design solutions are proposed that make possible an intensified fractionation of straw-grain heap. In the modified design of the lipped screen, the combs of the upper working sections of neighboring louver boards are offset by one half of the comb pitch The paper outlines the technological process of air-screen cleaning in a combine harvester. The uniformity of the air flow in the cleaning of the combine, which ensures the efficiency of the work, is considered. The authors give account of straw-grain flows supplied for cleaning in the form of a heap. The ways of dividing the heap into grain and the non-grain part are shown, in particular. To improve the cleaning process in a combine harvester, a number of design solutions have been proposed, which makes it possible to intensify the process of dividing straw-grain heaps into fractions. This provides for an increased heap division into grain and nongrain parts. To isolate small impurities, an additional fine-mesh sieve is installed in the cleaning system between the lower sieve and the inclined bottom. This is relevant when cleaning clogged weeds of crops. Grain falls on this sieve and slides over it to get to the grain auger, while fine impurities pass through the sieve. In order to remove these impurities from the cleaning system, a sluice gate is installed at the lower end of the inclined bottom. Such a design of the cleaning system allows obtaining cleaner grain in the combine harvester, which will result in reduced energy consumption in its post-harvest processing.
\end{abstract}

Keywords: combine harvester, louvre sieve, grain cleaning, air cleaning.

\section{Introduction}

Air-grid cleaning of the combine harvester is designed to separate the fine grain heap into two main fractions: grain and straw impurities. The pile reaching the clearing is a multi-component mixture consisting of grain, crashes (broken straw particles length $10 \ldots 100 \mathrm{~mm}$ ), chaff (spiked scales, particles of leaves, internal and external floral tape), weed seeds and inorganic litter. Consider the technological process of the combine cleaning system. To clean the processor receives a pile of three streams: the first through the bars of the concave threshing and separating device, the second of walkers and the third of the device [1]. The first stream contains up to $90 \%$ of the grain, the rest is chaff and crash. The second stream contains up to $50 \%$ of straw impurities [2]. The fractional composition of the third flow of the heap should be controlled to prevent multiple circulation of nonthreshed ears on the cleaning system (with the correctly selected settings of free grain in the flow of the heap it should be no more than 3...5\%). The grain heap of the three streams goes to the board. It makes oscillatory movements with tossing a heap to the side of the sieve. At the same time, the heap is moved and simultaneously it is delaminated into two main layers: the upper straw layer has a low density and the lower one, which is a mixture of grain, heavy inorganic impurities and non-threshed ears. However, simultaneously with delamination, the reverse process of mixing occurs, but the first still prevails [3]. At the end of the board partially divided into two layers the pile falls on the fingers, where the bottom layer, enriched grain and other small and heavy particles, falls on the sieve pan, and the top straw layer is moving on the fingers and picked up by the air flow from the fan [4].

\section{Materials and methods}

From the board the heap gets to the beginning of the upper sieve and is thrown up and divided into component parts under the action of the air flow . Light straw particles and the floor are lifted up by the air flow, and heavy particles (grains and ears) fall on the louvre surface of the sieve. The gaps in the sieves are adjusted so that the grain passes through them, and the straw particles and ears descend on the surface of the sieves at the end of the upper sieve at a slight angle to the extension of the upper sieve. The gap in the shutters of the extension blinds allows unshakable ears to pass through it to the ear auger, which sends the ears to be re-threshed. Light particles are removed from the cleaning system by the air flow. The grain passed through the upper and lower sieve gets on an inclined bottom and to the grain screw, and goes to the hopper [5]. 
Air-sieve cleaning can effectively operate when harvesting various crops thanks to the continuously variable adjustments: the velocity of the air gaps at the top and bottom sieves and the extension, angle of extension. Purification system produces the separation of the heap at the same time on several parameters: particle size, speed soared particles in the air flow, coefficient of friction (cohesion) of particles.

The purpose of the study is to improve the quality of the cleaning system of a combine harvester by improving its design. The problem of air sieve cleaning is the inefficient use of the air flow. The distribution of the air flow velocities over the area of the sieves varies. As the result, the air flow has the highest speed in the space between the sieve mill and boa rd that probably is a positive effect. This contributes to intensive loosening of the heap and release of grain from it. Some manufacturers specifically create an additional air channel from the fan to enhance this effect.

However, if a significant part of the air flow is directed between the grating mill and the shaking board, the air flow of less force passes through the sieve. The situation worsens with an increased supply of the mass for cleaning. There is a problem of reducing the aerodynamic drag of the cleaning system sieves. Profile louver sieves that are used most of the harvesters are $\Gamma$-shaped. This form of shutters creates turbulence of the air flow and provides additional aerodynamic resistance (Fig. 1).

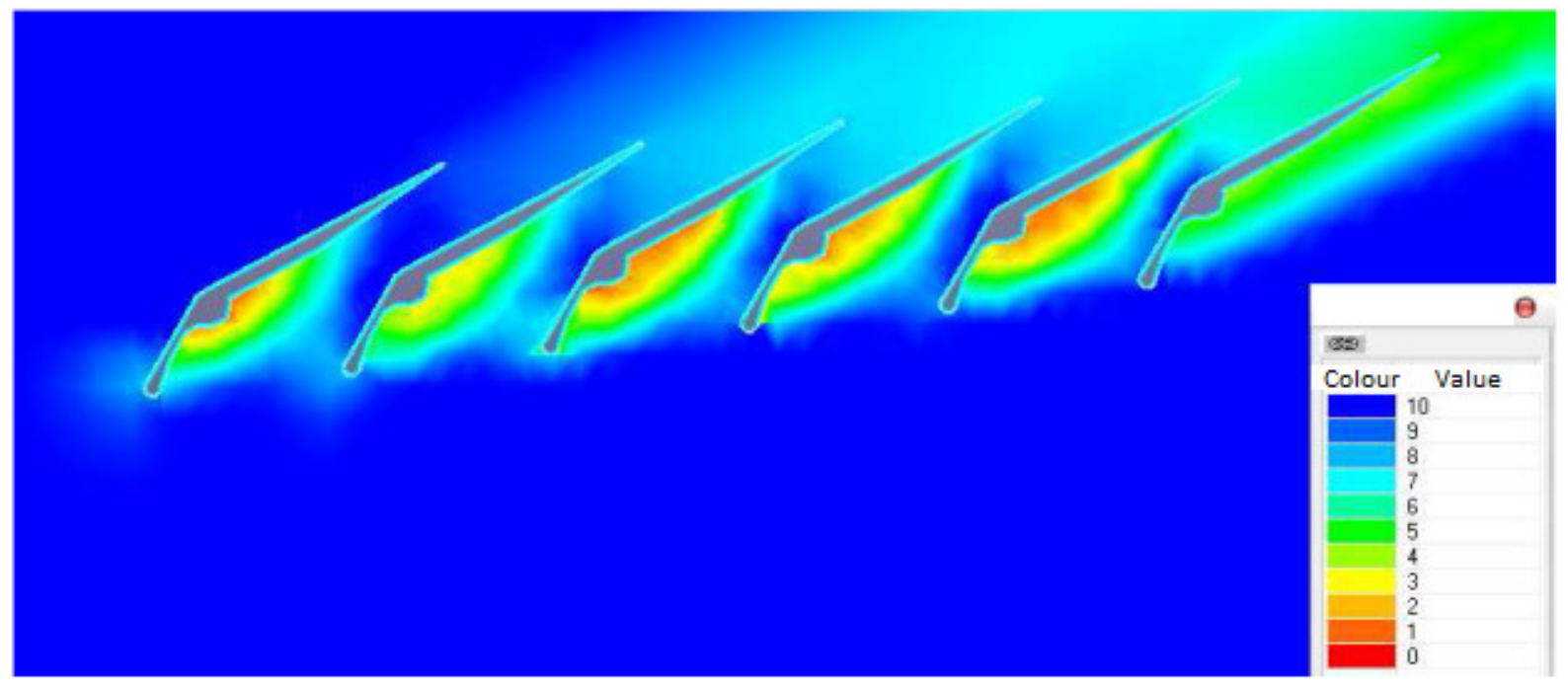

Fig. 1. Pressure zone of distribution of air flow at louvered sieve: deep blue and blue are areas of high pressure and continuous flow, orange and yellow are areas of low pressure and turbulence

The pressure of the air flow $\mathrm{R}$ on the seed can be determined by the formula

$$
R=m k_{n} u^{2},
$$

where $m$ and $k$-seed mass and sail ratio;

$u$ - relative air velocity;

Acceleration is obtained by the force $R$ from equation 1 :

$$
\frac{d v}{d t}=\frac{R}{m}=k^{u} u_{2}
$$

The sail coefficient factor depends on the air drag coefficient $k$, area $\mathrm{F}$ of the mid-section and the body $\mathrm{G}$ weight that determines its critical speed $v_{\text {кр }}$

$$
k n=\frac{k Y F}{G}=\frac{g}{v_{m p}^{2}} .
$$

For bodies having a regular shape, the area of the mid-section and weight can be determined by calculation. Seeds usually have an irregular shape, so it is better to determine the coefficient of sail, depending on the speed of soaring 


$$
\begin{aligned}
& R=\frac{m g u^{2}}{v_{m p}^{2}}, \\
& \frac{d v}{d t}=\frac{g u^{2}}{v_{s p}^{2}} .
\end{aligned}
$$

The working speed of the vertical air flow must be greater than the speed of the seed flow $v_{k p}$, which should be less than the speed $v_{\kappa p 2}$, which must be left in the general flow for further processing:

$$
v_{\kappa p 2}>u>v_{\kappa p 1}
$$

\section{Results and discussion}

One of the main indexes that influences the cleaning quality is equability of the air flow. Improving the performance of the cleaning system and improving the aerodynamic characteristics of the air flow with increased supply of grain-silt heap is possible by changing the design of the shutters of the louver. The staff of the Department of Agricultural Machinery proposed and patented the design of shutter blind sieve cleaning S-shape (Figure 2).
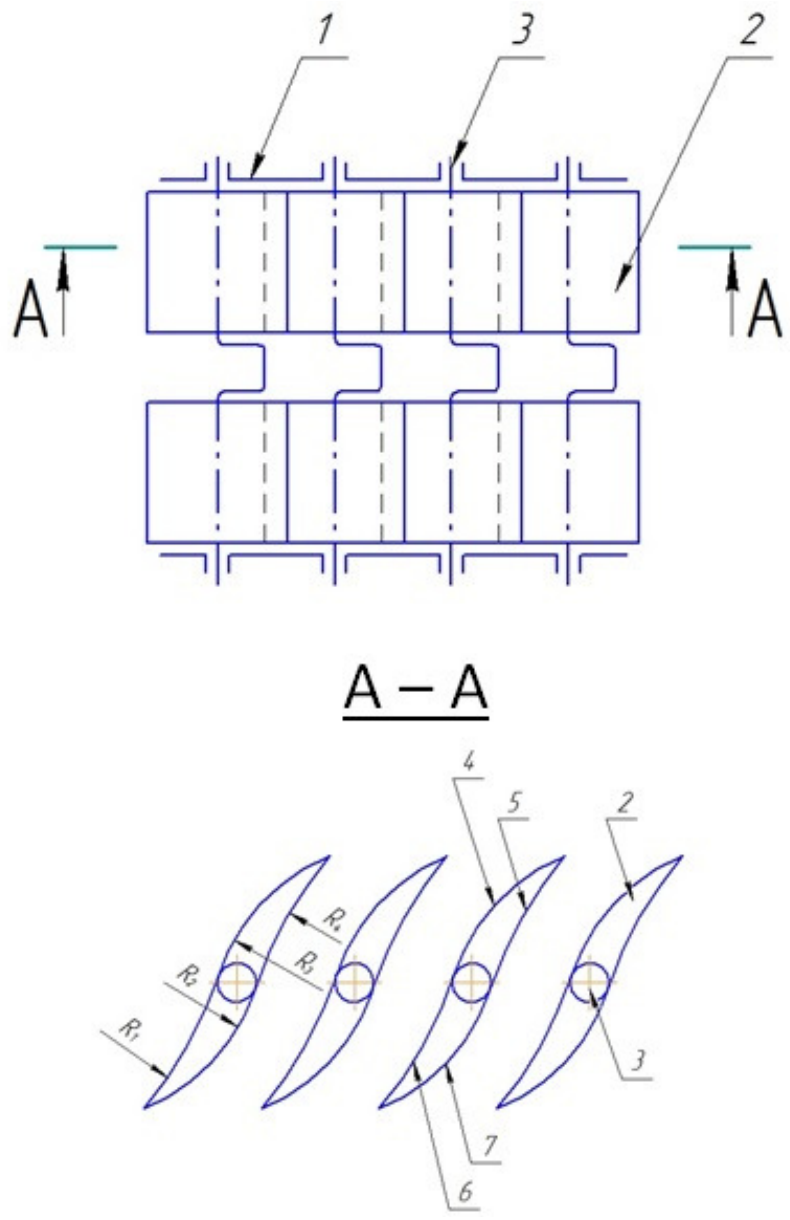

Fig, 2. Diagram of proposed louvred cleaning sieve sash, S-shaped

In the lower part of the shutter blinds the working and non-working surface are concave, and the ratio of the radius of curvature of the working surface to the radius of curvature of the non-working surface is in the range from 1.3 to 2.0, in the upper part the shutter working and non-working surface are concave, and the ratio of the radius of curvature of the working surface to the radius of curvature of the non-working surface is in the range from 0.5 to 0.8 . The limits of the change in the ratio of the radius of curvature of the surfaces are determined by the real values of the geometric dimensions of the shutters of the louver. The louver sieve of cleaning contains a frame 1 where the shutters of the louver $2 \mathrm{~S}$-shaped on the rotary axes 3 are installed. On the shutter 2, there are surfaces of the upper 
working 4, where the grain moves down, and the upper non-working 5, these surfaces are located above the rotary axis 3. There are also lower working 6 and non-working 7 surfaces located respectively below the rotary axis 3 . All surfaces of 4, 5, 6 and 7 S-shaped flaps 2 are concave. The ratio of the radius of curvature R1 of the lower working surface 6 to the radius of curvature R2 of the lower non-working surface 7 is in the range from 1.3 to 2.0, the ratio of the radius of curvature R3 of the upper working surface 4 to the radius of curvature R4 of the upper non-working surface 5 is in the range from 0.5 to $0.8[6]$.

The device works as follows. During the operation of the combine, the frame 1 of the louvered sieve makes an oscillatory motion together with the shutters 2 installed on it. The threshed mass coming out from under the threshing-separating device falls on the sieve. At the same time through the sash 2 louvered sieve the air flows from the fan (not shown), which affects the heap. Grain, which has a greater specific gravity than straw and chaff, falls through the space between the louver shutters 2 down on the bottom of the hull (not shown). Due to the flow of air and the oscillatory motion of the frame 1 of the louvered sieve $t$ the remaining mass is transported outside. When the working conditions change, it is possible to change the position of the shutters of the louver 2 with the help of the rotary axes 3 of the adjustment mechanism (not shown).

The shapes of the lower working 6 and non-working 7 surfaces of the flaps 2 louvered sieves, made in the form of concave surfaces, contribute to a uniform distribution of the air flow throughout the sieve and prevent the formation of vortices of the air flow at the entrance. The concave shape of the upper working 4 and non-working 5 surfaces eliminates the appearance of air turbulence at the exit from the comb.

A significant drawback in the operation of the air-sieve cleaning system is the impossibility of separating small weed impurities, which have a soaring speed comparable to the soaring speed of the grain. When harvesting cereal crops, these are mineral impurities, which include small stones, grains of sand and dust. In general, their content is small, and this practically does not affect the fulfillment of the agrotechnical requirements for the purity of bunker grain [7]. However, the presence of mineral impurities in the grain reduces its marketability, increases the load of post-harvest processing machines and represents a significant problem for the food industry (in particular, mills). The experience of harvesting white lupine showed that the cleaning system of a combine harvester is not able to separate the remains of the bean leaves, which, together with the grain, enter the bunker. In fact, the agrotechnical requirements for the purity of bunker grain when harvesting white lupine are not met. This problem can be solved by changing the design of the cleaning system. An additional fine sieve is installed in the cleaning system between the lower sieve and the inclined bottom. Grain, falling on this sieve, rolls down on it and gets to the grain auger, and small impurities pass through the sieve. In order to remove these impurities from the cleaning system at the lower end of the inclined bottom a sluice gate is installed [8].

The main index during the cleaning of grain heap is separation of weed plants. The proposed device (Figure 3) consists of shock boards 1, installed in front of the upper louvered sieve 2, with an extension 3 fixed on it, under which inclined bottoms 5 are installed, an additional fine-cell solution 6 fixed between them, an ear screw 7 located behind the lower end of the inclined bottom and the fan 10 is below the lower end of the inclined bottom.

The proposed device works as follows. A small grain pile arrives at the stacking board 1, where loosening and separation of the pile particles by density occurs. The prepared pile enters the upper louvered sieve 2, which separates the bulk of the grain, parts of the spikelets (beans) and particles of impurities that have a critical soaring speed close to the grains of the harvested crop (wet weed seeds during direct combining). Large impurities and a small component of the pile, which has a critical soaring speed less than that of the grain of the harvested crop, are removed by the air flow created by the fan 10 beyond the combine. On the extension of the upper louvered sieve 3 is the capture of the remaining unmilled spikelets (beans). The lower louvre sieve 4 divides the grain heap component that has passed through the upper louvre sieve into non-threshed spikelets (beans) that go to the ear screw 7 and the main grain with small weedy impurities that are not blown out of the air stream. This pile falls on an additional fine-meshed sieve 6 , where it is divided into clean grain, coming down into the grain auger 8 , and small impurities falling on the inclined bottom 5 . Then the small impurities are 
moved along the inclined bottom to its lower part and removed from the cleaning system using the airlock shutter 9 .

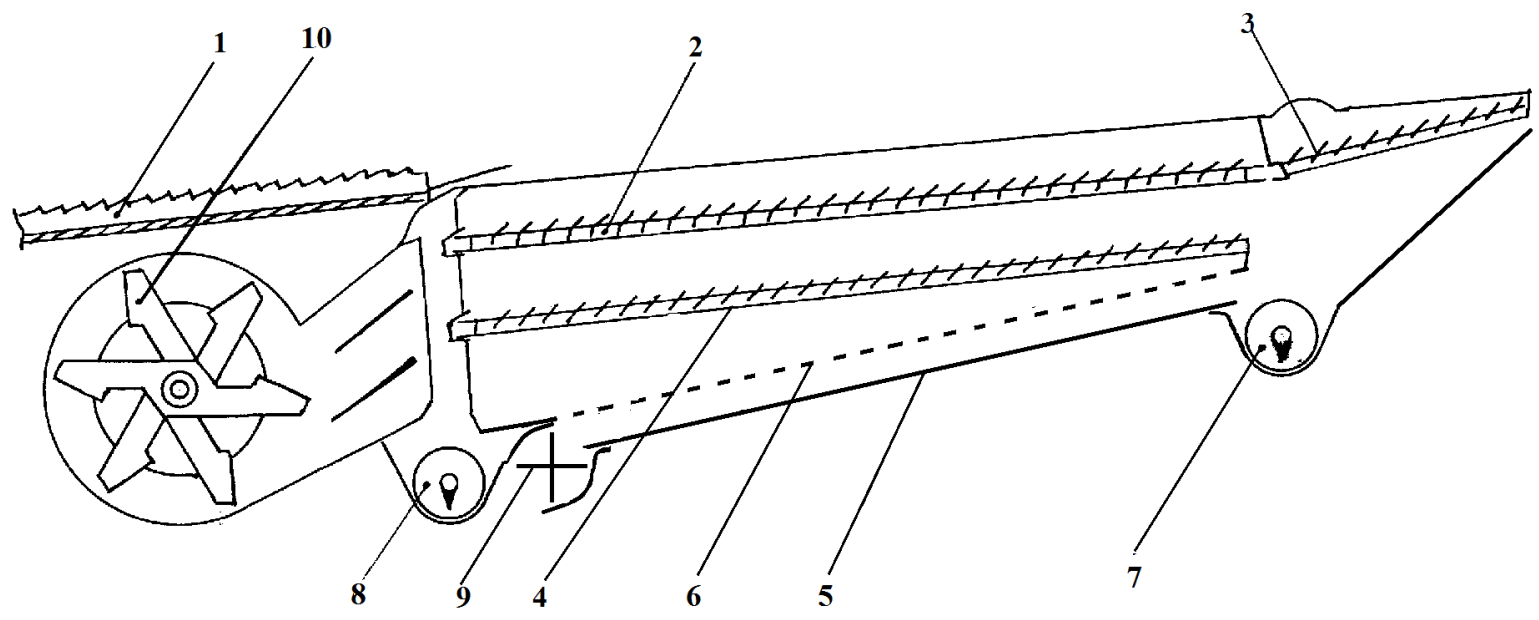

Fig 3. Device cleaning system with additional fine sieve: 1 - shakeboard; 2 - upper sieve; 3 - top sieve extension; 4 - lower sieve; 5 - sloping bottom; 6 - fine-meshed sieve; 7 - auger; 8 - grain auger; 9 - gate valve; 10 - fan

\section{Conclusions}

1. The louvre sieve of the combine harvester of the claimed design with S-shaped shutters has low resistance to the air flow, it allows to ensure the parameters of the air flow with better aerodynamic properties (speed, uniformity, directionality), which allows the system to clean the combine to work with an increased flow of heap and less grain.

2. Installing an additional sieve over an inclined bottom and a sluice gate at the lower end of the inclined bottom can improve the quality of grain cleaning and, moreover, it can reduce the energy consumption for its post-harvest processing.

\section{References}

[1] Aldoshin N., Didmanidze O. Harvesting lupines albus axial rotory combine harvesters / // Research in Agricultural Engineering.Scopus Vol. 64, 2018 (4): pp. 209-214.

[2] Constable G.,; Somerville B. (2003). A Century of Innovation: Twenty Engineering Achievements That Transformed Our Lives, Chapter 7, Agricultural Mechanization. Washington, DC: Joseph Henry Press. ISBN 0-309-08908-5.

[3] Miu. Combine Harvesters: Theory, Modeling, and Design CRC, 2016.

[4] Jech J .a kolektiv, Stroje pre rastlinnu vyrobu 3, Slovenska Pol'nohospodarska Univerzita,Nitra $2011,368 \mathrm{p}$.

[5] Ломакин С.Г., Бердышев В.Е. Анализ технологического уровня зерноуборочных комбайнов "Ростсельмаш».(Analysis of the technological level of combine harvesters "Rostselmash") Vestnik of Moscow State Agricultural Engineering University 2017, №6 (82) pp. 34-42 (In Russian)

[6] Ожерельев В.Н., Жалнин Э.В., Никитин В.В. Перспективы развития конструкции зерноуборочного комбайна Prospects for the development of the design of a combine harvester. (Energy efficiency and energy supply in modern production and society).(Proceedings of the international scientific-practical conference). 2018. pp. 137-143. (In Russian)

[7] Жалнин Э.В. Ценч Ю.С., Пьянов В.С. Методика анализа технического уровня зерноуборочных комбайнов по функциональным и конструктивным параметрам (Methods for analyzing the technical level of combine harvesters by functional and design parameters) (Agricultural machinery and technology journal, v.12., 2018 №2, pp. 4-8. (In Russian) 